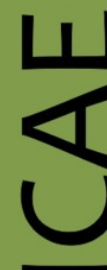

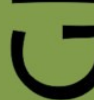

ex Instituto Archaeologico Universitatis de Rolando Eötvös nominatae

O

$\overrightarrow{0}$

山

$\leftarrow$

I

$\cup$

ه

$\leftarrow$

u

Ш

Z

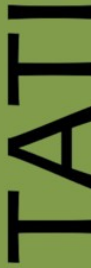

œ

ш

n

n

$\varnothing$
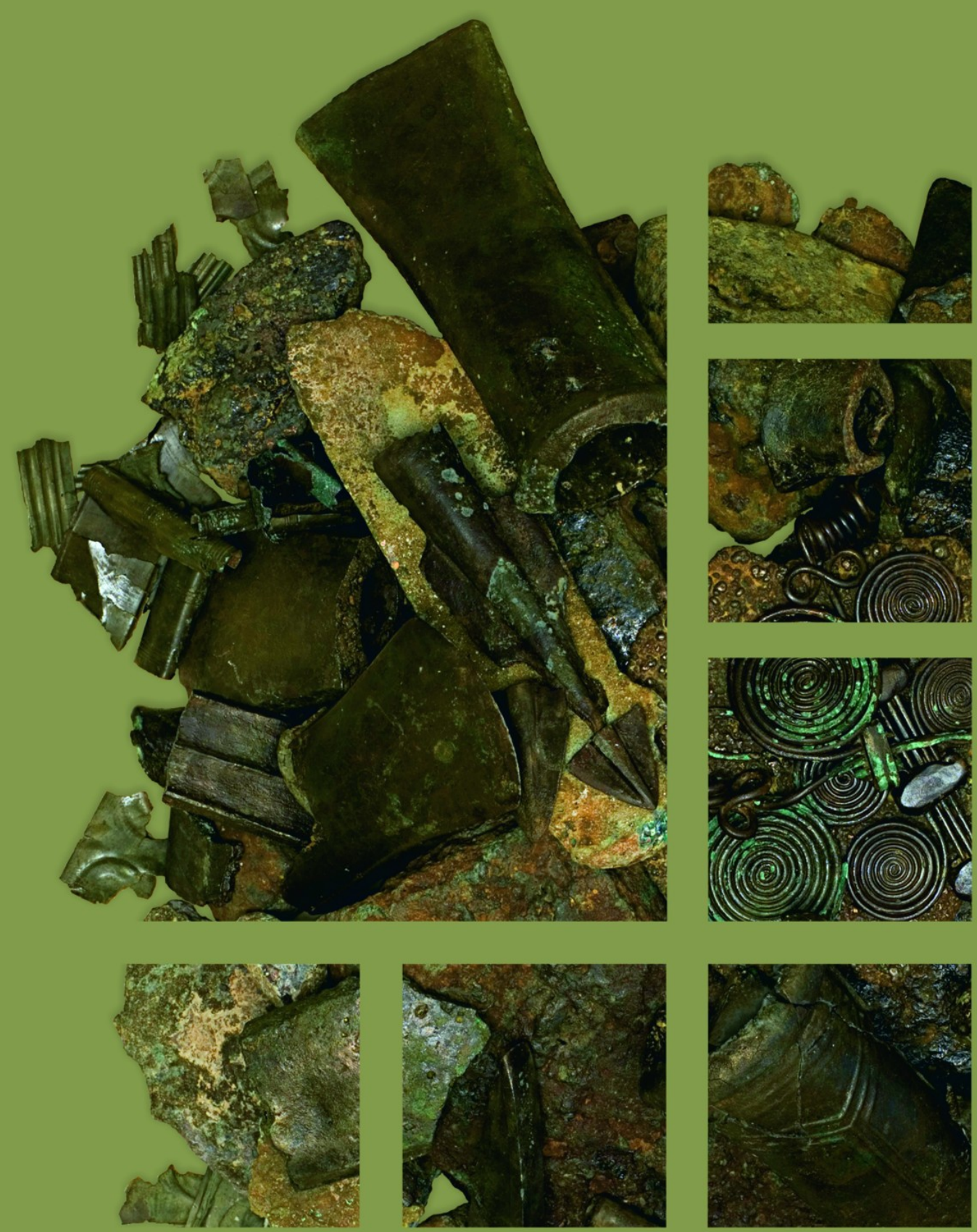


\section{Dissertationes Archaeologicae ex Instituto Archaeologico}

Universitatis de Rolando Eötvös nominatae Ser. 3. No. 2.

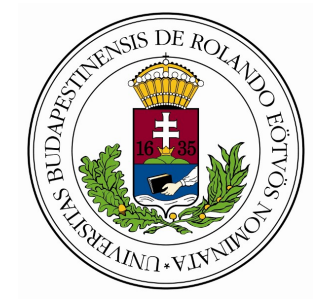

Budapest 2014 
Dissertationes Archaeologicae ex Instituto Archaeologico Universitatis de Rolando Eötvös nominatae

Ser. 3. No. 2.

Editor-in-chief:

DÁvid BARTus

Editorial board:

LÁsZló BARTOSIEWICZ

LÁSZLÓ BORHY

IsTVÁN FELD

GÁBOR KALLA

PÁL RACZKY

MiKLÓs SzABÓ

TIVADAR VIDA

Technical editors:

DÁvid BARTus

GÁBOR VÁCZI

ANDRÁs BÖDŐCS

DÁNIEL SZABÓ

Proofreading:

SZILVIA SzÖLLősI

Available online at http://dissarch.elte.hu Contact: dissarch@btk.elte.hu

$$
\begin{aligned}
& \text { PUBLIC } \\
& \text { KNOWLEDGE } \\
& \text { PROJECT }
\end{aligned}
$$

(c) Eötvös Loránd University, Institute of Archaeological Sciences

Budapest 2014 


\section{Contents}

\section{SElected PAPERS OF THE XI. Hungarian CONFERENCE on Classical Studies}

Ferenc BARNA

Venus mit Waffen. Die Darstellungen und die Rolle der Göttin in der Münzpropaganda

der Zeit der Soldatenkaiser (235-284 n. Chr.)

Dénes GABLER

A belsó vámok szerepe a rajnai és a dunai provinciák importált kerámiaspektrumában

Lajos MATHÉDESZ

Római bélyeges téglák a komáromi Duna Menti Múzeum gyújteményében

Katalin OtTOMÁNYI

Újabb római vicusok Aquincum territoriumán

Eszter SÜVEGH

Hellenistic grotesque terracotta figurines. Problems of iconographical interpretation

András SzABó

Some notes on the rings with sacred inscriptions from Pannonia

István VIDA

The coinage of Flavia Maxima Helena

\section{Articles}

Gábor TARBAY

Late Bronze Age depot from the foothills of the Pilis Mountains

Csilla SÁRó

Roman brooches from Paks-Gyapa - Rosti-puszta

András BöDőcs - Gábor KovÁcs - Krisztián ANDERKó

The impact of the roman agriculture on the territory of Savaria

Lajos JuHÁsz

Two new Roman bronzes with Suebian nodus from Brigetio

\section{FIELD REPORTS}

Zsolt MESTER - Norbert FARAGó - Attila KirÁLy

The first in situ Old Stone Age assemblage from the Rába Valley, Northwestern Hungary

Pál RACZky - Alexandra ANDERs - Norbert FARAgó - Gábor MÁRKus

Short report on the 2014 excavations at Polgár-Csőszhalom 
Preliminary Report on the first season of fieldwork in Berettyóúffalu-Szilhalom

Márton SzILÁgyi - András FüZESI - Attila VIRÁG - Mihály GASPARIK

A Palaeolithic mammoth bone deposit and a Late Copper Age Baden settlement and enclosure

Preliminary report on the rescue excavation at Szurdokpüspöki - Hosszú-dúlö II-III. (M21 site No. 6-7)

Kristóf FüLÖP - Gábor VÁcZI

Preliminary report on the excavation of a new Late Bronze Age cemetery

from fobbágyi (North Hungary)

Lőrinc TimÁr - Zoltán CzAJLik - András BöDőcs - Sándor PuszTA

Geophysical prospection on the Pâture du Couvent (Bibracte, France). The campaign of 2014

Dávid BARtus - László Borhy - Gabriella Delbó - Emese SzÁmadó

Short report on the excavations in the civil town of Brigetio (Szőny-Vásártér) in 2014

Dávid BARTus - László BorHy - Emese SzÁMADó

A new Roman bath in the canabae of Brigetio

Short report on the excavations at the site Szőny-Dunapart in 2014

Dávid BARTus - László Borhy - Zoltán CzAjlik - Balázs Holl -

Sándor PuszTA - László RuPNiK

Topographical research in the canabae of Brigetio in 2014

Zoltán CZAJLIK - Sándor BERECKI - László RUPNIK

Aerial Geoarchaeological Survey in the Valleys of the Mureș and Arieș Rivers (2009-2013)

Maxim MoRDovin

Short report on the excavations in 2014 of the Department of Hungarian Medieval

and Early Modern Archaeology (Eötvös Loránd University, Budapest)

Excavations at Castles Čabrad' and Drégely, and at the Pauline Friary at Sáska

\section{Thesis Abstracts}

Piroska Csengeri

Late groups of the Alföld Linear Pottery culture in north-eastern Hungary

New results of the research in Borsod-Abaúj-Zemplén County

Ádám Bíró

Weapons in the 10-11th century Carpathian Basin

Studies in weapon technology and methodology - rigid bow applications and southern import

swords in the archaeological material

Márta DARÓcZI-SzABó

Animal remains from the mid 12th-13th century (Árpád Period) village of Kána, Hungary

Károly BELÉNYESY

A 15th-16th century cannon foundry workshop in Buda

Craftsmen and technology of cannon moulding and the transformation of military technology

from the Renaissance to the Post Medieval Period 
István RINGER

Manorial and urban manufactories in the 17th century in Sárospatak

\section{BIBLIOGRAPHY}

László BORHY

565

Bibliography of the excavations in Brigetio (1992-2014) 


\title{
Roman brooches from Paks-Gyapa - Rosti-puszta
}

\author{
CSIlla SÁRÓ \\ Institute of Archaeological Sciences \\ Eötvös Loránd University \\ sarocsilla@gmail.com
}

\begin{abstract}
The main aim of this paper is the typological classification of the 31 Roman Age brooches recovered at the archaeological site of Paks-Gyapa - Rosti-puszta. There are several pieces among the brooches discussed in the paper to which no exact parallels have yet been published from the territory of Pannonia. Beside the detailed classification of the brooches observations concerning their fabrication and decoration technique were also discussed. In general, the pieces can be dated to the Early and Middle Roman Age, however the aim of identifying exact typologycal groups as well as presenting paralells was to create a basis to a more precise dating of the objects.
\end{abstract}

\section{Introduction}

In 2008, a preventive excavation was carried out by the Institute of Archaeological Sciences of the Eötvös Loránd University at the site of Paks-Gyapa - Rosti-puszta (M6-TO15). ${ }^{1}$ The excavation site was over 41.000 square metres and several phenomena from the Middle $\mathrm{Ne}$ olithic, Early-, Middle- and Late Bronze Age, Iron Age and Roman Age were documented. ${ }^{2}$ 31 brooches and brooch fragments dating back to the Early and Middle Roman Ages ${ }^{3}$ were found in the archaeological site. Except for four pieces, ${ }^{4}$ all of these are stray finds and they can be discussed in eight main types. The Early and Middle Roman Age brooches from this site were at first presented in my MA thesis. ${ }^{5}$ In the current study, these artifacts are classified and discussed in detail.

\section{Typology}

\section{Type 1. The Aucissa type (Cat. 1)}

One semi-broken brooch belongs to this type. The pin is hinged in a narrow, appressed tube which fixes the axis bar. This brooch can be classified as Berecz A242.3. subtype based on its size, the type of the hinged pin and the shape of the bow.

K. Berecz supposed that the production of this subtype took place near the coast of the Adriatic Sea in Dalmatia or in South-Pannonia (in the region of Siscia-Emona-Salonae). According to K. Berecz this Aucissa subtype was in use between the second half of the 1st century $\mathrm{BC}$ and the first decades of the 2nd century AD.

1 The leader of the excavation was Gábor Váczi. I would like to express my gratitude to him for the opportunity of pub lishing the Roman brooches.

2 Füzesi András is responsible for the Neolithic finds: FüZesI 2012.

3 Cat. 29. is an exception; it dates back to the Late Roman Age.

4 Cat. 2, Cat. 4, Cat. 28, Cat. 30.

5 SÁró 2011. 


\section{Type 2. „Norisch-pannonische Flügelfibeln” (Cat. 2-5)}

Four Norisch-pannonische Flügelfibeln were found in Paks-Gyapa - Rosti-puszta; all of them are broken. The spring is constructed of 8-10 turns with an external chord; the cross section of the bow is semicircular, farther narrower and plate-like. The catchplate is wide and also plate-like. This type was first examined by O. Almgren ${ }^{6}$ and later in detail by J. Garbsch ${ }^{7}$ and W. Jobst. ${ }^{8}$ The brooches from Paks-Gyapa belong to the second group of W. Jobst which includes two further subtypes.

Type 2.a. (= Kovrig T. II,12. $=$ Patek A.1.2. típus $=$ Garbsch A 238c $=$ Sedlmayer 2.46)

The catchplate is pierced by round holes. Cat. 2 is broken but the first row of holes can be observed. The wings are undecorated; the wing-knobs were inserted later.

Type 2.b. (= Kovrig T. II,11. = Patek A.1.1. típus = Garbsch A 238v)

The catchplate can be decorated in many ways; for example with small pointed circles in the case of Cat. 3 and Cat. 4. Moreover, the catchplates are decorated with chasing ("Wolfszahnmuster", pine-twig pattern). Cat. 5 has a special form: it has a small "Sehnenkappe" and flared wings, decorated with $2+1$ later inserted, divided knobs. The classification was made based on the form of the plate-like bow: similar bows appear in the case of a brooch pair from the grave No. 1 of Nagyvenyim ${ }^{9}$ and one brooch from the tumulus No. 56 of Pátka. ${ }^{10}$

According to J. Garbsch the A238c type is common in Southwest-, Northwest- and Northeast-Pannonia ${ }^{11}$ and less common in Noricum. ${ }^{12}$ The recently published brooches from Budaörs ${ }^{13}$ and Sárbogárd ${ }^{14}$ confirm the Pannonian distribution area, while Cat. 2 attests a southern distribution frontier. J. Garbsch dated this type from the beginning of the late Claudian period to circa $130 \mathrm{AD},{ }^{15}$ but later he modified the end of the period to the beginning of the Tiberian age. ${ }^{16}$ The brooches from dated layers at Magdalensberg suggest that the type appeared earlier, in the late Tiberian - early Claudian period. ${ }^{17}$

According to J. Garbsch the A238v type is mostly from Northern- and Eastern Pannonia. Although the list of these brooches may be broadened nowadays ${ }^{18}$ the distribution area is the same discussed above. The type was in use in the 2nd century AD. ${ }^{19}$ The brooches from PaksGyapa are similar to those from the cemetery in Solymár: the form of the catchplates and

\footnotetext{
6 Almgren 1923, 108-109, 211, Taf. XI. 238.

7 GARBSCH 1965, 49-77.

8 JoBst $1975,49-51$.

9 VÁgó 1960, 46, Abb. 4, Taf. XXXV. 1-2; Garbsch 1965, 75, Abb. 40.19, A238v/Nr.19-20; SÁró 2011, 114-115, Kat. 35-36.

10 PAlágyi - NAgy 2000, 35, 139, T. XV. 7; SÁró 2011, 117-118, Kat. 46.

11 Garbsch 1965, 53-54, Karte 9.

12 GARBSCh 1965, 53; Sedlmayer 2009, 29.

13 Merczi 2012, Kat. 59-63, 5. kép 1-2.

14 BÁNKi 1998, 75, Abb. 10/grave 21/1-2, Abb. 20. 7-8.

15 GARBSCH 1965, 53.

16 Garbsch 1974, 173, Abb. 5.

17 Sedlmayer 2009, 75.

18 For example some recently presented Garbsch A238v brooches: In my MA thesis I presented 18 brooches from the ter ritory of Fejér and Tolna County (SÁró 2011, 17-19, Kat. 12-16, 18-21, 46-47, 54-55, 59-60, 67-70, 72-73), four pieces have recently been presented from the settlement in Budaörs (MERCZI 2012, 490, 6. kép 1-3), four brooches are known from the cemetery in Sárbogárd (BÁNKi 1998, Abb. 20. 3-6) and 20 brooches are known from the cemetery in Solymár (Kocztur 1991, IV. T. 8-9, VII. T. 4, XIV. T. 9a-b, XVI. T. 5, XIX. T. 4a, XX. T. 1, XXVI. T. 19-20, XXVIII. T. 14-15, XXXI. T. 10-11, XXXV. T. 3, 10, XXXVIII. T. 12-13, XXXIX. T. 14, XL. T. 23).

19 GARBSCH 1965, 75.
} 
their decorations are similar. The brooch from the grave No. 23 is dated by an as of Hadrian. ${ }^{20}$ This data confirms that this type was in use before the middle of the 2nd century AD.

Type 3. „Doppelknopffibeln” (Cat. 6)

A single piece is known from Paks-Gyapa. The external chord is held by a plain hook. The characteristics (small size, triangular shape of the open catchplate, semicircular cross section of the bow) classify the brooch to the A236c type in J. Garbsch's typology, common in Southwest-Pannonia, ${ }^{21}$ less known in Noricum, Raetia, Germania Superior ${ }^{22}$ and Dacia. ${ }^{23}$ Brooches of this type were in use in the 1st century AD.

\section{Type 4. „Kräftig profilierte Fibeln” (Cat. 7-17)}

This is the largest group of brooches from Paks-Gyapa: eleven pieces belong to the "Kräftig profilierte Fibeln". The main characteristic - the crossbar - is discernible. They can be divided into two subtypes:

Type 4.a. (= Almgren 68. = Kovrig VIII. (V. T. 41-44.) $=$ Patek A.5. (IV. T. 9-10.) $=$ Jobst I.4.b. = Rieckhoff 4.5.2. $=$ Riha 2.9.2. $=$ Bojović 9.2. $=$ Schleiermacher VIII.2. $=$ Ortisi 7.c. $=$ Cociş $8 a 1 b 1,8 a 1 b 2 a)$

The brooches consist of a one-piece construction. The cross section of the upper bow is semicircular while that of the lower bow is circular/oval. The bow is divided by a knob and ends in a multi-part knob. The catchplate is triangular or rectangular and pierced by holes.

All brooches belonging to this type (4.a) are broken or fragmentary. None of them were decorated with three holes, which is the earliest version of round perforations. ${ }^{24}$ In the case of Cat. 7-11, the catchplate is decorated with two holes; except for Cat. 11, holes are of the same size. ${ }^{25}$ Catchplates of Cat. 8, 11 and Cat. 10 are long and similar to the Kovrig 42 type. Catchplate of Cat. 12 is pierced by one hole; the form and the footknob are similar to a brooch from Magdalensberg. ${ }^{26}$

This subtype is most common in Pannonia ${ }^{27}$ and Noricum, ${ }^{28}$ and it occurs from the Rhineland ${ }^{29}$ to the Black Sea. ${ }^{30}$ They are known from the Barbaricum, ${ }^{31}$ but are far less common in Britain and Gaul. ${ }^{32}$ In Magdalensberg, this subtype appears in the late Augustan-Tiberian period..$^{33}$ Its usage started in Pannonia probably at the same time. The brooches from Budaörs and Páty are

20 RIC 669 (KoczTUR 1991, 178).

21 GARBSCH 1965, 29.

22 Garbsch 1965, 29; Sedlmayer 2009, 27, Taf. 9. 228, 230, Taf. 10. 233-259, Taf. 11. 260-266, 268-269, Abb. 93, 98, 103.

23 Cociş 2004, 72, pl. XXXIX. 603-604, pl. XL. 605-606.

24 PATEK 1942, 22.

25 One hole of Cat. 11. is mismade. It is rectangular and smaller than the normal hole.

26 The catchplate is decorated with a single hole as well: SEDLMAyER 2009, Taf. 21.449. A similar footknob is discernible in the case of a brooch-type with unperforated catchplate. For example: Rieckнoff 1975, Taf. 2.17-18; RiHA 1979, Taf. 9.245; Ortisi 2002, Taf. 6.76-77. This type is known from the cemetery in Sárbogárd: BÁNKi 1998, Abb. 2/Grave 4/1, Abb. 22.1.

27 Kovrig 1937, 44-46; PAтeK 1942, 167-172; SÁró 2011, 28, Kat. 89, 99-102, 107, 121, 137, 145, 153-154, 158-160, 163165, 167, 170, 175, 178-179, 182, 185, 187-188, 191, 194, 196; MERCZI 2012, 482-483.

28 Kovrig 1937, 16; Patek 1942, 22; Jobst 1975, 32-33, Taf. 1. 8, Taf. 2. 9-10; Kropf - Nowak 1998-1999, Taf. 2. 6 , Taf. 7. 28; Sedlmayer 2009, 32-33, Taf. 19. 374-375, Taf. 20, Taf. 21.

29 Ettlinger 1973, 62-63, Taf. 18. 4-7; Rieckhoff 1975, 90, Taf. 2. 15-16; Riha 1979, 73-74, Taf. 9. 232-234; Schliermacher 1993, 20-21, Taf. 6. 66-69, Taf. 7, Taf. 8. 83; Rina 1994, 69-70, Taf. 7. 1981-1983; Ortisi 2002, 20, 22, Taf. 5. 56-60, 62-63, 65.

30 Bojović 1983, 33; Cociş 2004, 48, 167, pl. V. 65, 67, 69, 71, 72, 74-76.

31 LamiovÁ-Schmiedlová 1961, Tab. IV. 5-10; PešKař 1972, 78, tf. 9. 4-9, tf. 10. 1-5, 7.

32 Lerat 1956, pl. II. 49-50; Feugère 1985, 438-439; SNAPe 1993, 13; Simpson 2000, 6; Bayley - Butcher $2004,59$.

33 Sedlmayer 2009, 64, Tab. 33. The earliest version of the subtype was dated to 11/12 AD terminus post quem (SEDLMAYER 2009, 33). 
datable: Merczi 2012/7 variant brooches from Budaörs can be dated to the Claudian and Flavian period based on the dated layers ${ }^{34}$ and the brooches from Páty were in use from the last third of the 1st century to the beginning of the 2nd century AD. ${ }^{35}$ A brooch from Magdalensberg dated to the Claudian age ${ }^{36}$ is a close parallel to Cat. 12.

Type 4.b. $(=$ Almgren 69. $=$ Kovrig VIII. $=$ Patek A.5. = Jobst I.4.c)

Cat. 13-15 belong to this subtype. Both one-piece and two-piece constructions are common, the spring is of 8-10 turns with an external chord. The cross section of the upper bow is semicircular and that of the lower bow is circular/elliptical/triangular. The unperforated catchplate is triangular or trapezoidal.

Type 4.b.1. (= Riha 2.9.2. = Cociş 8a1c1-2)

Cat. 13 and 14 have a similar form, but the central knob is different: Cat. 13 has a profiled central knob, while Cat. 14 has a semi-profiled central knob. Some brooches from Budaörs ${ }^{37}$ are comparable to Cat. 13-14, but they are bigger than the brooches from Paks-Gyapa. A similar brooch is also known from grave No. 3 of the cemetery in Sárbogárd. ${ }^{38}$ This was put into the grave along with an "Augenfibel" and a "Kräftig profilierte Fibel". The former can be dated to the first half of the 1st century $\mathrm{AD}$ and the latter to the Claudian period. ${ }^{39}$ Parallels of Cat. 1314 are also known outside of Pannonia, from Augusta Raurica, ${ }^{40}$ Dacia, ${ }^{41}$ and the Barbaricum. ${ }^{42}$

Type 4.b.2. (= Riha 3.1. = Cociş 8a9)

The flared hook, the pin attachment, the step at the junction of the bow and crossbar and the semi-profiled central knob are the main characteristics of Cat. 15.

In Pannonia, some examples are known from Budaörs, ${ }^{43}$ Siscia ${ }^{44}$ and Tolna County. ${ }^{45}$ Furthermore, outside of Pannonia, similar brooches are published from Augusta Raurica, ${ }^{46}$ Dacia $^{47}$ and Moesia. ${ }^{48}$ An analogue subtype with facetted upper bow is also known from several provinces of the Roman Empire. ${ }^{49}$ Unfortunately, the closest parallel from Budaörs could not be dated based on the context. According to S. Cociş, this subtype (Cociş 8a9) can be dated to the first half of the 2nd century AD.

34 Merczi 2012, 509-510, 2. táblázat, Nr. 20, 21, 22, 23, 25, 26, 27, 28, 29, 31, 32, 33.

35 OtTomÁnYi 2007, 140, 151.

36 Sedlmayer 2009, 86, Tab. 77.

37 Merczi 2012, 4. kép 1-2. They are broken and stretched, that is why the original form is not known. The brooches be long to the Merczi M. 8/10. variant and they are parallel to Cocis 8a1c1 type (MERCZI 2012, 484).

38 BÁNki 1998, Abb. 2/grave 3/3, Abb. 22. 3. Its size is almost of that of our brooches (BÁNKI 1998, 65).

39 BÁNKI 1998, 93.

40 RiHa 1979, Taf. 9. 236.

41 Cocis 2004, pl. VI. 79, 88, 90.

42 From the excavation site in Púchov and in Sučany, and from the collection of the Slovenské narodné múzeum v Martine (LAmiovÁ-SchmiedlovÁ 1961, Tab. IV. 11, 12, Tab. XIII. 2), in addition, Mikulov, Postoupky and Uherské Hradiště (PEŠKA Ř 1972, 38, 57, 71, Taf. 10.8, Taf. 11.2, 5). The upper bows are slightly facetted, which differ from the homologue part of our brooches.

43 Merczi 2012, 486, 8/14, 4. kép 7.

44 KoščEvić 1980, T. XVI. 118, T. XVIII. 131

45 SÁró 2011, 156, Kat. 193.

46 Riнa 1979, Taf. 11. 274.

47 Cocış 2004, pl. XVIII. 254.

48 Bojović 1983, T. X. 85-86.

49 It is known from Pannonia: Majs (Burger 1972, 69, 74/22. kép 81, 27. kép/Grave 22/5), Zala County (Berecz 1991, 3. kép 7.) and Tolna County (SÁRó 2011, 151-152, 155-156, Kat. 176, 190, 193). It occurs in the Barbaricum (PEŠKAř 1972, 55, Taf 12.5), in Dacia (Cociş 2004, pl. XVIII. 255), in Singidunum (Bojović 1983, T. X. 87-88) and in Vindonissa (EtTlinger 1973, Taf. 18.18). 
Even though Cat. 16-17 are fragmentary, they are generally classifiable: they belong to the type of "strongly profiled brooches with crossbar". Based on the shape of the bow, Cat. 16 can belong to 4.a. as well as 4.b.1. The catchplate is missing, therefore no further observations can be made. The catchplate of Cat. 17 is also missing and the bow is broken. The upper bow resembles some published brooches,${ }^{50}$ but Cat. 17 cannot be precisely classified.

\section{Type 5. Knee brooches (Cat. 18-19)}

Two fragmentary brooches belong to this type. They might have had a spring construction.

Type 5.a. (= Berecz I. E-G-3. ${ }^{51}=$ Merczi B/2. változat ${ }^{52}$ )

Cat. 18 is characterized by a semicircular headplate, a semicircular cross section and a semicircular step at the junction of the bow and the headplate. The decoration of the headplate is very common in this subtype. The end of the bow has broken down, but originally the brooch had a typical Pannonian form: it is arched in the middle, and has wider ends.

This type is very common in Pannonia, ${ }^{53}$ in Noricum ${ }^{54}$ and in Upper Moesia, ${ }^{55}$ furthermore it occurs in Dacia ${ }^{56}$ and in the Barbaricum. ${ }^{57}$

Type 5.b. (= Berecz I.1. = Merczi B/9. változat)

Cat. 19 has a special form: above the now missing spring (?) the bow is widened, then its profile is slightly arched and the bow becomes plate-like. This form has the characteristics of two brooch types: first, the wide bow makes it similar to the "trumpet headed stongly profiled brooches", while the slightly arched bow profile is typical of the "knee brooches". Two similar brooches were published by D. Bojović and R. Koščević. In the typology of D. Bojović it ${ }^{58}$ belongs to the knee brooches, but some differences can be observed: the brooch from Singidunum has a less expanded section and the lower bow is not widened but the sides are arched. The brooch from Siscia is a close parallel to Cat. 19. The missing pin-attachement of Cat. 19 can be reconstructed based on the brooch from Siscia, which has a spring in a tube. But it is also possible that it had a looped spring construction, like the "Trompetenfibeln".

If this subtype is studied in the typological evolution, it gains an important position. For a long time, knee brooches and trumpet headed brooches were assumed to derive from the "Kräftig profilierte Fibel". Based on this, I suggest that Cat. 19 and the brooch from Siscia should be considered as examples of an important derivation step after the "Kräftig profilierte Fibel".

\section{Type 6. „Trumpet headed brooches” and „Pannonian trumpet brooches” (Cat. 2O-24)}

Five brooches belong to this type, none of them have crossbars.

50 Some parallels are known from Singidunum (Bojović 1983, T VIII. 67). Except for the facetted surface, a brooch from Budaörs is also similar to Cat. 17 (Merczi 2012, 2. kép 4).

51 BERECZ 1987.

52 MerCZi 2011.

53 Koščević 1980, T. XXIII. 180, 184, 187; BereCZ 1987, I. E-3: 82-116, I. F-3: 117-144, 146, I. G-3: 148-161; Berecz 1990, Abb. 4. 10, 13; Berecz 1991, 4. kép 7; Otтományi 2007, 140. kép 7, 141. kép 2; Merczi 2011, 32, 11-13/Nr. 29-43, 45-48, 50-58; MercZi 2012, 30-32, 7. kép 3, 10.

54 JoBst 1975, Taf. 22. 160-162, 166-168.

55 Bojović 1983, T. XIX. 169-175.

56 Cociş 2004, pl. LVI. 818, pl. LVII. 833, 839, pl. LX. 881-882.

57 LamiovÁ-Schmiedlová 1961, Tab. XIV. 14, 16; PešKAř 1972, Taf. 17. 4, 7, 9-10, Taf. 18. 1, 3; VAdAy 1988-1989, Abb. 13. $2-5,10$.

58 Bojović 1983, T. XXII. 210. 
Type 6.a.1. (= Kovrig VIII. (VII. T. 62.) = Jobst I.5.d. = Merczi 12. típus/1. változat ${ }^{59}$ )

Cat. 20-21 are one-piece brooches, Cat. 21 has a looped spring of 16 turns. The beginning of the bow resembles a trumpet, then the knob is leaf-like. Both of the lower bows are decorated: the edges and the surface of Cat. 20 are decorated with chased circles, while the surface of Cat. 21 is decorated with a wavy relief pattern.

Close parallels of Cat. 21 are known in Pannonia from Aquincum, ${ }^{60}$ Budaörs, ${ }^{61}$ Solymár ${ }^{62}$ and Tolna County. ${ }^{63}$ Furthermore, similar brooches in larger sizes are known from Kiskajdacs ${ }^{64}$ and from an unknown site from Tolna County. ${ }^{65}$ In the Catalogue of I. Kovrig, small and large pieces are mixed under one subtype, they are known from the whole territory of Pannonia. ${ }^{66}$ This subtype is also known from Lauriacum, but the brooch is decorated in a different way. ${ }^{67}$

Cat. 20-21 can be dated based on some brooches from datable Pannonian find contexts. First of all, the grave "A" from Aquincum can be dated from the first half of the 2nd century to the first half of the 3rd century AD based on the finds. ${ }^{68}$

A brooch of this type was found together with a "Kräftig profilierte fibel" in grave No. 33 in Solymár. ${ }^{69}$ The looped spring construction and a trumpet-shaped bow makes it similar to the "trumpet headed brooches" ${ }^{\prime 0}$ which dates back to the 1st-2nd century AD. ${ }^{71}$

A parallel of Cat. 20-21 was found together with a "Norisch-pannonische Flügelfibel" in grave No. 145 in Solymár. ${ }^{72}$ Its catchplate is decorated with frequently pointed small circles. Based on the form, this brooch belongs to Garbsch A238v (here: 2.b.) and dates back to the 2nd century $\mathrm{AD}$ (see above). The find context of the brooches from Budaörs confirms that they were in use in the 1 st-2nd century. ${ }^{73}$

These data suggest a long period of usage of the subtype.

\section{Type 6.a.2.}

The trumpet-shaped bow of Cat. 22 makes the brooch similar to 6.a. subtype, but it differs in the form of the central knob and in the decoration. In spite of the fragmentation of Cat. 22, some parallels can be found, the closest one is known from Flavia Solva. ${ }^{74}$ Similar decoration of the trumpet-shaped bow from Saalburg is presented by A. Böhme, ${ }^{75}$ from Mikulov

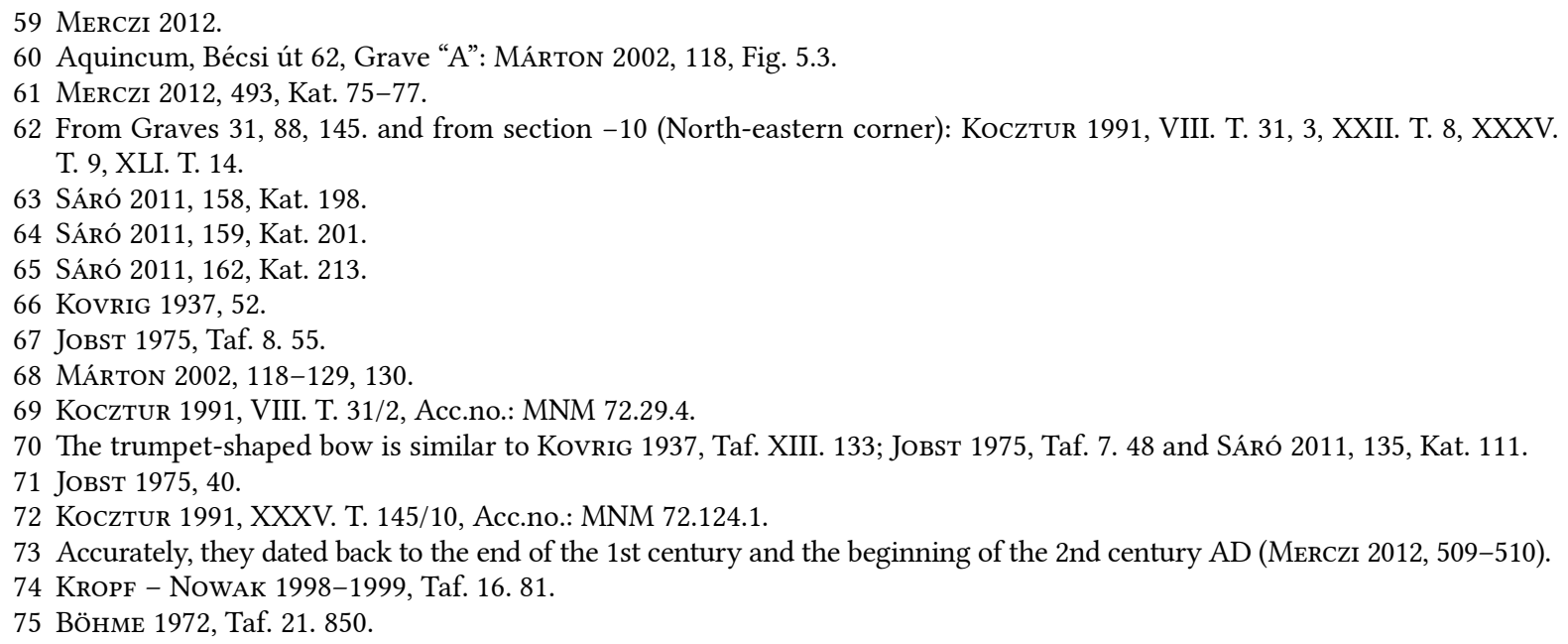


by I. Peškař, ${ }^{76}$ from Siscia by I. Kovrig and R. Koščević. ${ }^{77}$ Although these brooches are similar to Cat. 22, all of them differs a little: the brooches from Siscia differ in the size of the trumpet-shaped bow and in the multi-rolled silver stripe, while the brooches from Saalburg and Mikulov differ in the arch of the bow.

Type 6.b. $(=$ Jobst I.6.a. $=$ Koščević 14.4. = Bojović 12.3. = Cociş 21.b)

Although Cat. 22 is fragmented, its type can be defined. The thrice divided central knob, the leaf-like lower bow, the divided end-knob and the unperforated catchplate makes Cat. 22 similar to type Kovrig 65. Similar pieces are published from Pannonia, ${ }^{78}$ from Noricum, ${ }^{79}$ from Dacia $^{80}$ and from Singidunum. ${ }^{81}$

Since Cat. 23 is very fragmentary, it has not been analysed typologically. Based on the bow form, Cat. 23 should belong to "trumpet headed strongly profiled brooches". The trumpet-shaped bow makes it similar to type Kovrig 60, which is known from several parts of Pannonia. ${ }^{82}$

Type 7. Enamelled brooches (Cat. 25-26)

Two brooches are decorated with enamel. The bow forms are different: Cat. 25 is a bow brooch, while Cat. 26 is a plate brooch.

\section{Type 7.a.}

The fragmentary Cat. 25 might belong to group Berecz IA,$^{83}$ but a similar bow forepart is not known. ${ }^{84}$ It could have had a segmented bow similar to E. Ettlinger Taf. $11,8 .{ }^{85}$ or R. Hattatt Fig. $180,870 .{ }^{86}$

\section{Type 7.b. $\left(=\right.$ Feugère $29 a 14 c=$ Berecz $^{87} I I C / 2 b$ altípus ${ }^{88}$ )}

Cat. 26 has a hare-shaped plate bow, decorated with enamel cells which form the outline of two small hares and a hexagram between them. Some parallels are known from Pannonia: six pieces from Carnuntum, five pieces from Komárom-Esztergom County, two pieces from Loretto, one piece from Wiener Neustadt and one piece from Katzelsdorf. ${ }^{89}$ This subtype also appears in several parts of the Roman Empire: it is known from Britannia, ${ }^{90} \mathrm{Gallia},{ }^{91}$ Asciburgium, ${ }^{92}$ Submuntorium ${ }^{93}$ and Singidunum. ${ }^{94}$ Half-made brooches from Népelier ${ }^{95}$ and

76 PEŠKA ̌̌ 1972, 167, Taf 13. 3.

77 Kovrig 1937, 54, Taf. VII. 71; Koščević 1980, T. XXI. 161, T. XXII. 164-165, 169.

78 Kovrig 1937, 53; PAtek 1942, 200-201; Siscia: KoščEvić 1980, T. XXI. 160; Tolna County: KovRIG 1937, 17, 53, Taf. VII. 65. (The brooch from Tolna County see also: PATeK 1942, 201, [Kovrig VII. T. 65.] típus/Nr. 14; SÁró 2011, 162, Kat. 212).

79 KROpF - NowAK 1998-1999, Taf. 16. 83.

80 Cociş 2004, pl. XCVII. 1362-63.

81 These central knobs are flatter and consist of less segment (BoJović 1983, T. XVI. 143-144).

82 Kovrig 1937, 51-52; SÁRó 2011, 33.

83 This kind of bow brooches, have one axis of simmetry and segmented bow (BERECZ 2008, 73).

84 Maybe type Berecz IA/5 is close to the form of Cat. 25. (BErecz 2008, 80, 2. típustábla).

85 EtTLINGER 1973.

86 HATtATt 1989.

87 BERECZ 2008.

88 I. Sellye and E. Patek presented some hare-shaped brooches with enamel decoration (SELLYE 1939, XIII. T. 1-5; PATEK 1942, XXI. T. 13-14, 17-18), but they didn't know any brooch in the form of Cat. 26.

89 Matouscheк - Nowak 1981-1982, Taf. 3. 25-28; Matouschek - Nowak 1985-1986, Taf. 21. 8-11; Berecz 2008, Kat. C-90, 91, 153, 214-218, 373.

90 Hattatt 1989, 171, Nr. 1632; Bayley - Butcher 2004, 124, 260, cat. 353.

91 Feugère 1985, 408; Hattatt 1989, 171, Nr. 1633.

92 Bechert 1973, Taf. 10. 94.

93 Ortisi 2002, 44, Taf. 23. 419.

94 Bojović 1983, Taf. XXX. 291.

95 FEUGÈre 1985, 408. 
Kleinwinterheim ${ }^{96}$ can be considered as a proof of local brooch production. Based on the distribution area around Carnuntum, K. Berecz supposed that this subtype was produced in Pannonia. ${ }^{97}$

None of the brooches from Pannonia can be precisely dated; K. Berecz dated them only on the basis of bibliographical references. ${ }^{98} \mathrm{~A}$ brooch from Winchester is known from a context of $60 \mathrm{AD},{ }^{99}$ while a brooch from Loddon is dates back to 50-75 $\mathrm{AD}$.

Type 8. Zoomorphic brooches (Cat. 27-28)

Two zoomorphic brooches without enamel decoration have been found in Paks-Gyapa, both of them are plate brooches. Cat 27 has a spring construction with external chord, while Cat. 28 has a hinged pin between two lugs.

\section{Type 8.a.}

The bow of Cat. 27 forms an ungulate; unfortunately the head has broken down. The fur is made of chased dashes. Based on its physical appearance, it could depict a horse or a deer.

Horse-shaped plate brooches illustrate several horse gaits (standing, ${ }^{100}$ jumping, ${ }^{101}$ galloping and grazing ${ }^{102}$ ), presenting the animal with two or four legs. Deer-shaped brooches illustrate the animal with two ${ }^{103}$ or three ${ }^{104}$ legs. Unfortunately, this information is not useful in this case since Cat. 27 is represented with two legs, so it can belong to both categories.

The answer is given by a plate brooch from Szekszárd, ${ }^{105}$ which is complete and its bow forms a deer. The two animals' bodies are similar, so Cat. 27 is likely to be a deer as well. Both brooches are from Tolna County and no more close parallels are known. ${ }^{106}$

\section{Type 8.b.}

Cat. 28 is a zoomorphic-compositional brooch: it consists of two animals and an object. Genre-compositional brooches were published from Pannonia by I. Sellye, ${ }^{107}$ E. Patek, ${ }^{108}$ and K. Berecz $^{109}$ but the non-enamelled zoomorphic-compositional brooch type was unknown before.

The bow represents a goblet between two animals (maybe two seahorses). This composition is known from France and Switzerland, but just one similar brooch has been found so far. ${ }^{110} \mathrm{~A}$ composition of two chimaeras and a goblet is published from Vindonissa; ${ }^{111}$ a composition of two dolphins and a goblet is known from Yverdon ${ }^{112}$ and Mediolanum. ${ }^{113}$ A plate brooch from

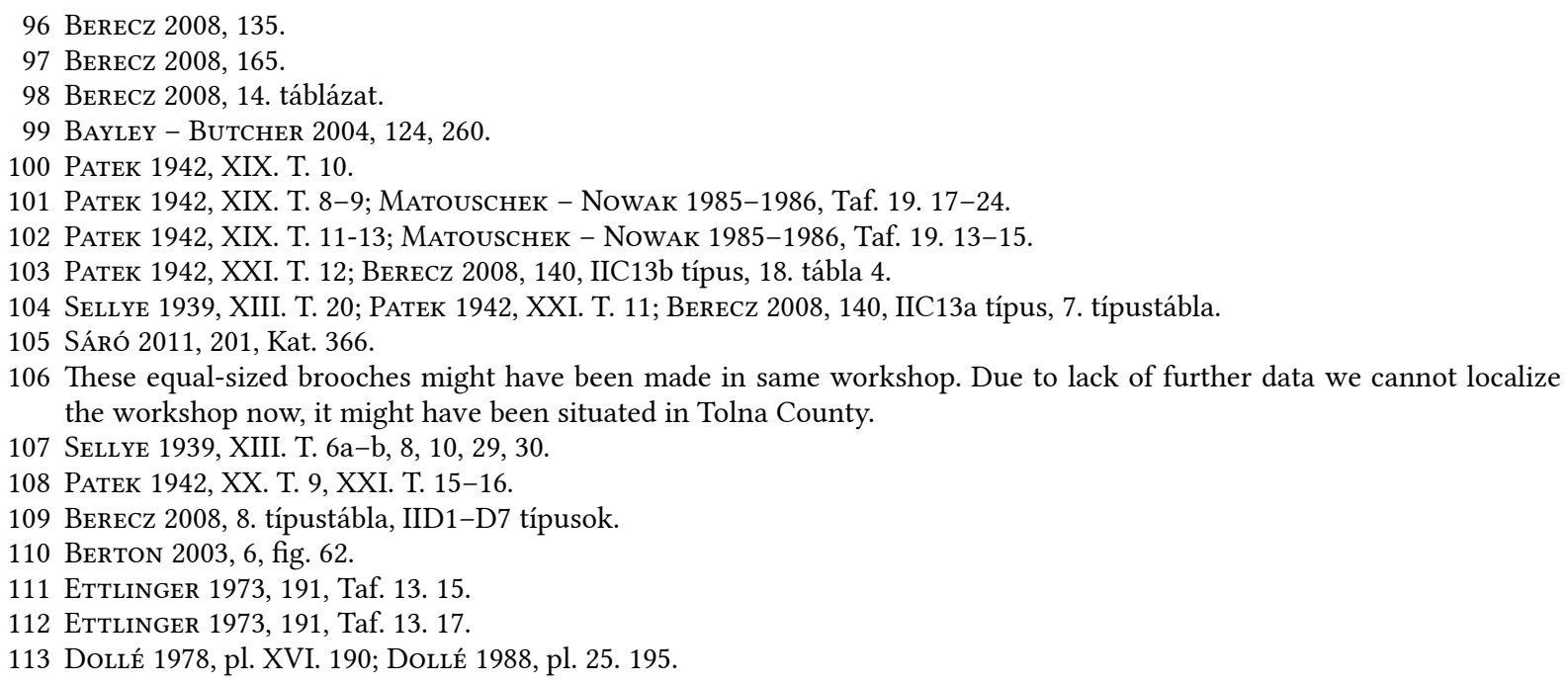


Vertillum presents two snakes and a goblet ${ }^{114}$ and a similar piece is known from Augusta Raurica, a goblet between two dragons/griffins. ${ }^{115}$ Cat. 28. cannot be dated based on the find context; a parallel provides an indication: the brooch from Mediolanum dates back to the 1st century AD.

\section{Type 9. Unclassified brooches (Cat. 29-31)}

Cat. 29 might be a Late Roman „T-brooch” or a „Crossbow brooch”. The fragment of the bow has a highly arched bow profile and a rectangular cross section, embellished by two knobs on the top of the bow and a stamped decoration on the exterior side.

Cat. 30-31 are presented in the study, but they are defined as uncertain brooches. Cat. 30 is extremely fragmentary. If it belonged to a brooch, it might have been a piece of a large-sized catchplate, for example "Norisch-pannonische Flügelfibel" or "Doppelknopffibel". Based on the pierced holes and the chased "Wolfszahnmuster", Cat. 31. may belong to a "Norisch-pannonische Flügelfibel" or "Doppelknopffibeln" as well.

\section{The manufacture and decoration of the brooches}

Above we presented 31 brooches: except for Cat. 14, Cat. 21 and Cat. 27, all brooches are broken or fragmentary. The discussed brooches are made of copper alloy, except for two pieces (Cat. 18 and Cat. 20) which are made of silver. All brooches were made by casting; some traces can be recognized on Cat. 4-5, 13-14 and 18. One of the pierced holes of Cat. 11 is improperly made.

29 brooches from Paks-Gyapa can be discussed in nine types. Except for three plate brooches (Cat. 26-28) the others are bow brooches. There are one-piece as well as two-piece brooches and three methods of pin attachment can be observed. The most common pin attachment is the "spring with external chord" in the case of both the one-piece (Cat. 2, 4-6, 10-12, 14, 16-17, 21, 27) and two-piece (Cat. 15) brooches. A „hinged pin in a narrow tube” (Cat. 1, 25) and a „hinged pin between two lugs” (Cat. 26, 28) are also noticeable.

The high-standard decoration is enamelling: Cat. 25-26 serve as an example for this method. Unfortunately, no enamel has remained in the cells of Cat. 26 and only two small pieces appear in the cells of Cat. 25.

Cat. 21 and Cat. 22 are the two examples for inlaid decoration. In the case of Cat. 21, the lower bow is decorated with a copper alloy wire, while in the case of Cat. 22, the edge of the trumpet-shape bow and the central knob is decorated with an inlaid silver wire.

Some other techniques appear as well, like chasing and stamping. Small, chased lines, "Wolfszahnmuster", zigzag and pine-twig patterns are arranged into "X" pattern (Cat. 3. and a winding-curve (Cat. 5) or they can also serve for decorating the edges (Cat. 4-5, 18, 20-21, 23-24) or filling (Cat. $23,27)$ the surfaces. Small pointed circles decorate the catchplate of Cat. 4 , the lower bow of Cat. 20 and the junction-plate of Cat. 25. Cat. 29 is the only example for stamping. 


\section{Catalogue}

Abbreviations:

A.N. = accession number

$\mathrm{L}=$ length

$\mathrm{W}=$ width

F.c. $=$ find context

Cat. 1. (Fig. 2.2)

A.N.: 30727.000 .166 .

Two-piece bronze brooch. The bow is semibroken, the axis bar, the pin and the catchplate are missing. Originally the pin is hinged in a narrow tube form from the top of the bow rolled back, above the headplate. Both edges of the plain headplate are arched. The bow is slightly arched and decorated with two longitudinal ribs.

L: 2,65 cm; W: $1,8 \mathrm{~cm}$; F.c.: stray find (GPS: $\mathrm{N}$ 632742 - E $148393 ;-150 \mathrm{~cm})$.

Cat. 2. (Fig. 1.1)

A.N.: 30727.311 .047$.

One-piece bronze brooch. The catchplate is broken, the spring is damaged. The spring is of $5+1$ turns with an external chord; it is held by a plain hook and fastened by an axis bar. The cross section of the bow is semicircular, divided by a plain, oval knob and two wings, afterward the bow is narrow. The wings are decorated with one cylindrical knob (the other one is missing). The large catchplate is pierced by seven round holes.

L: 12,1 cm; W: 3 cm; F.c.: OBJ: 311, STR: 442.

Cat. 3. (Fig. 3.2)

A.N.: 30727.000 .161$.

Fragmentary bronze brooch. The bow is broken, the spring and the pin are missing. The small bow section is rolled back on the exterior side. The rectangular catchplate turns right, it is decorated with small pointed circles and chased pine-twig pattern.

L: $7,7 \mathrm{~cm}$; W: $0,3 \mathrm{~cm}$; F.c.: stray find (GPS: $\mathrm{N}$ 632692 - E 148 425; surface).

Cat. 4. (Fig. 3.1)

A.N.: 30727.433 .109$.

One-piece bronze brooch. The catchplate is broken. There are some seams on the surface of the bow. The spring is of $4+2$ turns with an external chord; it is held by a plain hook. The cross section of the bow is semicircular, di-

vided by a bulge-like knob and two wings, from that point on the bow is narrow. The wings are decorated with $1+1$ small, cylindrical knobs. The narrow bow section is rolled back on the exterior side, decorated with chased "Wolfszahnmuster" on the interior side. The catchplate is decorated with small pointed circles and chased "Wolfszahnmuster".

L: 9 cm; W: 2,3 cm; F.c.: OBJ: 433, STR: 589.

\section{Cat. 5. (Fig. 2.1)}

A.N.: 30727.000 .149$.

One-piece bronze brooch. The catchplate is broken. There are some seams on the surface of the bow. The spring is of $5+5$ turns with an external chord; it is held by a small "Sehnenkappe" and fastened by an axis bar. The "Sehnenkappe" is decorated with chasing: several small lines are ranged into two stripes. The cross section of the bow is semicircular, divided by a plain, oval, two-piece knob and two wings, from that point on the bow is narrow. The wings are decorated with $2+1$ two-piece (cylindrical body, semi-globe head) knobs. The narrow bow section is decorated with chasing: several small lines are ranged into two winding-curves. The narrow bow section is rolled back on the exterior side.

L: $13 \mathrm{~cm}$; W: 2,8 cm; F.c.: stray find (GPS: $\mathrm{N}$ 632722 - E 148432$)$.

Cat. 6. (Fig. 1.2)

A.N.: 30727.000 .153$.

One-piece bronze brooch. The spring is broken, the pin is missing. The spring is of 3 turns with an external chord; it is held by a plain prismatic hook. The cross section of the bow is semicircular, faceted, divided by two knobs (twice divided, plain); between the knobs the cross section of the bow is circular. The footknob is of two-pieces: plain and cylindrical. The open catchplate is triangular.

L: 4,3 cm; W: $1,6 \mathrm{~cm}$; F.c.: stray find (GPS: $\mathrm{N}$ 632725 - E 148142 ). 
Cat. 7. (Fig. 5.6)

A.N.: 30727.000 .101$.

One-piece bronze brooch. The spring and the pin are missing, the second part of the bow is deformed. The upper bow profile is highly arched. The cross section of the bow is semicircular, the central knob is twice divided, profiled. The lower bow is narrower, with elliptical cross section; the footknob consists of two pieces: a plain part and a truncated cone. The catchplate is trapezoidal, pierced by two holes. L: $4,3 \mathrm{~cm}$; W: $1,8 \mathrm{~cm}$; F.c.: stray find (GPS: $\mathrm{N}$ 632716 - E 148449$)$.

Cat. 8. (Fig. 1.3)

A.N.: 30727.000 .164 .

One-piece bronze brooch. The spring and the pin are missing. The hook is plain, prismatic; the crossbar is cambered, rectangular. The upper bow and the central knob is similar to Cat. 7. above. The lower bow is narrower, with oval cross section. The footknob consists of three pieces: a rim, an oval part and a cylindrical knob. The catchplate is long and triangular, pierced by two holes.

L: $4 \mathrm{~cm}$; W: 1,4 cm; F.c.: stray find.

Cat. 9. (Fig. 5.3)

A.N.: 30727.000 .160 .

Fragmentary bronze brooch. The bow is semibroken, the spring and the pin are missing. The cross section of the bow is elliptical; the central knob is twice divided and oval; the footknob consists of two pieces: an oval and a cylindrical part. The catchplate is trapezoidal, pierced by two holes.

L: $4 \mathrm{~cm}$; W: $1,3 \mathrm{~cm}$; F.c.: stray find (GPS: $\mathrm{N}$ 632792 - E 148 491; surface).

Cat. 10. (Fig. 1.4)

A.N.: 30727.000 .163 .

One-piece bronze brooch. The spring is broken, the pin is missing, the second part of the bow is deformed. The spring is of 4 turns with an external chord; it is held by a plain prismatic hook; the crossbar is cambered, rectangular. The upper bow profile is highly arched. The cross section of the bow is semicircular, the central knob is twice divided, profiled. The lower bow is narrower, with oval cross section. The footknob consists of three pieces: a rim, an oval part and a cylindrical knob. The catchplate is long and trapezoidal, pierced by two holes.
L: $4,1 \mathrm{~cm}$; W: $1,6 \mathrm{~cm}$; F.c.: stray find (GPS: $\mathrm{N}$ 632741 - E $148464 ;-30 \mathrm{~cm}$ ).

Cat. 11. (Fig. 1.5)

A.N.: 30727.000 .150 .

One-piece bronze brooch. The spring is broken, the pin is missing, the second part of the bow is deformed. The spring is of four turns with an external chord; it is held by a plain prismatic hook; the crossbar is slight, rectangular. The upper bow profile is highly arched. The cross section of the bow is semicircular, the central knob is once divided, profiled. The lower bow is narrower, with circle cross section. The footknob consists of three pieces: a rim, an oval part and a cylindrical knob. The catchplate is long and triangular, pierced by one hole, and an improperly made squared-formed hole. L: $5,2 \mathrm{~cm} ; \mathrm{W}: 2,1 \mathrm{~cm}$; F.c.: stray find.

Cat. 12. (Fig. 2.3)

A.N.: 30727.000 .162 .

One-piece bronze brooch. The spring and the hook are broken, the pin is missing. The spring is of two turns with an external chord; it is held by a plain prismatic hook; the crossbar is cambered, rectangular. The upper bow profile is highly arched. The cross section of the bow is semicircular, the central knob is profiled; the cross section of the lower bow is elliptical. The footknob is elongated, drop-formed. The catchplate is trapezoidal, pierced by one hole.

L: $3,4 \mathrm{~cm}$; W: $1,2 \mathrm{~cm}$; F.c.: stray find (GPS: $\mathrm{N}$ 632768 - E 148486 ; $-35 \mathrm{~cm})$.

Cat. 13. (Fig. 4.1)

A.N.: 30727.000 .156 .

One-piece bronze brooch. The spring is broken, the pin is missing. There are some seams on the surface of the bow. The hook is plain, prismatic; the crossbar is cambered, rectangular. The cross section of the bow is semicircular, the central knob is profiled; the cross section of the lower bow is circular. The footknob consists of two pieces: the oval part ends in a nib. The catchplate is trapezoidal, unperforated. L: $4,3 \mathrm{~cm}$; W: $1,2 \mathrm{~cm}$; F.c.: stray find (GPS: $\mathrm{N}$ 632746 - E 148462 ; surface).

Cat. 14. (Fig. 5.2)

A.N.: 30727.000 .154

One-piece bronze brooch. Complete. The second part of the bow is deformed. There are 
some seams on the surface of the bow. The spring is of $4+4$ turns with an external chord; it is held by a plain prismatic hook. The crossbar is cambered, rectangular. The cross section of the bow is semicircular, the central knob is once divided, semi-profiled; the cross section of the lower bow is elliptical. The footknob consists of two pieces: a rim and a truncated cone. The catchplate is trapezoidal, unperforated.

L: $5,7 \mathrm{~cm}$; W: $2,1 \mathrm{~cm}$; F.c.: stray find (GPS: $\mathrm{N}$ 632767 - E 148 446; surface).

Cat. 15. (Fig. 5.1)

A.N.: 30727.000 .152 .

Two-piece bronze brooch. The spring is broken, the pin is missing. The spring is of five turns with an external chord; it is held by a cylindrical flared hook, fastened by an axis bar; the crossbar is rectangular. The upper bow expands towards a narrower neck at the head; the cross section of the bow is semicircular, with a rib downside. The central knob is onepiece, semicircular; the cross section of the lower bow is triangular. The footknob consists of two pieces: the oval part ends in an elongated semicircular knob. The catchplate is rectangular, unperforated.

L: $6,1 \mathrm{~cm}$; W: $2,2 \mathrm{~cm}$; F.c.: stray find (square $\mathrm{HF}-25$; house).

Cat. 16. (Fig. 2.4)

A.N.: 30727.000 .151$.

One-piece bronze brooch. The spring, the axis bar and the bow are broken, the pin is missing, the catchplate is damaged. The spring is of three turns with an external chord; it is held by a plain prismatic hook and fastened by an iron axis bar; the crossbar is rectangular. The upper bow profile is highly arched. The cross section of the bow is semicircular; the central knob is twice divided, profiled. The cross section of the lower bow is elliptical. The small remain of the catchplate is trapezoidal.

L: $4 \mathrm{~cm}$; W: $1,8 \mathrm{~cm}$; F.c.: stray find (GPS: N 632820 - E 148457$)$.

Cat. 17. (Fig. 5.7)

A.N.: 30727.000 .165 .

One-piece bronze brooch. The spring and the bow are broken, the pin is missing. The spring is of four turns with an external chord; it is held by a plain prismatic hook; the crossbar is rectangular. The upper bow profile is highly arched. The cross section of the elongated, the flown bow is semicircular. The central knob is twice divided, profiled. The central knob is once divided, profiled.

L: $2,4 \mathrm{~cm}$; W: $1,6 \mathrm{~cm}$; F.c.: stray find (GPS: $\mathrm{N}$ 632738 - E 148381).

\section{Cat. 18. (Fig. 2.5)}

A.N.: 30727.000 .158 .

Two-piece silver brooch. The bow is semi-broken, the pin and the catchplate are missing. There are some seams on the surface of the crossbar. It has a forward-facing hook, a semicircular headplate and a step at the junction of bow and headplate. The exterior and interior edge of the headplate is decorated with a chased zigzag pattern. The cross section of the bow is semicircular.

L: $2,5 \mathrm{~cm}$; W: $1,4 \mathrm{~cm}$; F.c.: stray find (GPS: N 632776 - E 148504; surface).

Cat. 19. (Fig. 4.2)

A.N.: 30727.000 .167 .

One-piece bronze brooch. Secondary burnt. The catchplate is broken, the spring and the pin are missing. Above the remains of the hook, the bow is expanded, resembling a truncated cone. The cross section of the upper bow is semicircular; the lower part is tapering. The end of the triangular lower bow is cut down. The catchplate is rectangular.

L: $2,9 \mathrm{~cm}$; W: $1 \mathrm{~cm}$; F.c.: stray find (GPS: $\mathrm{N}$ 632743 - E $148483 ;-90 \mathrm{~cm})$.

Cat. 20. (Fig. 4.4)

A.N.: 30727.000 .147 .

One-piece silver brooch. The spring and the pin are missing. The beginning of the bow resembles a trumpet. The cross section of the bow is semicircular; the central knob is profiled. The edge of the trumpet-shaped bow is engrailed. The tapering lower bow part is oval, its edges and the surface are decorated with chased circles. The footknob consists of two pieces: the oval part ends in cylindrical knob. The unperforated catchplate is pentangular.

L: $3,1 \mathrm{~cm}$; W: 0,9 cm; F.c.: stray find (GPS: $\mathrm{N}$ 632730 - E 148430$)$. 
Cat. 21. (Fig. 4.3)

A.N.: 30727.000 .169 .

One-piece bronze brooch. Complete. The spring is deformed. The looped spring is of $8+8$ turns with an external chord; it is fastened by an axis bar. The beginning of the bow resembles a trumpet. The cross section of the bow is semicircular; the central knob is twice divided, profiled. The tapering lower bow part is oval. The edges are engrailed and the surface is decorated with wavy relief pattern. The footknob consists of two pieces: the oval part ends in a cylindrical knob. The unperforated, long catchplate is trapezoidal.

L: $3,1 \mathrm{~cm}$; W: 2,4 cm; F.c.: stray find (GPS: $\mathrm{N}$ 632743 - E $148987 ;-130 \mathrm{~cm}$ ).

Cat. 22. (Fig. 4.5)

A.N.: 30727.000 .105 .

Fragmentary bronze brooch. Only the upper part of the bow. The beginning of the bow is likened to a trumpet, the edge is decorated with a silver stripe. The cross section of the bow is semicircular; the central plain knob is twice divided, each knob is decorated with silver stripes.

L: $1,65 \mathrm{~cm}$; W: $1,1 \mathrm{~cm}$; F.c.: stray find (GPS: $\mathrm{N}$ 148442 - E 632715).

Cat. 23. (Fig. 4.8)

A.N.: 30727.000 .148 .

Fragmentary bronze brooch. The bow is semibroken, the spring and the pin are missing. The cross section of the bow is elliptical. The central knob is thrice divided, the four steps of the knob are decorated with chased zigzag pattern. The lower cross section of the leaf-shaped lower bow is triangular; the edges are decorated with chased "Wolfszahnmuster" and the middle of the surface is decorated with chased triangles. The unperforated catchplate is trapezoidal the edges of the external side are also decorated with chased "Wolfszahnmuster".

L: $2,8 \mathrm{~cm}$; W: $1,2 \mathrm{~cm}$; F.c.: stray find (GPS: $\mathrm{N}$ 632740 - E 148465$)$.

Cat. 24. (Fig. 4.7)

A.N.: 30727.000 .061$.

Fragmentary bronze brooch. Only the upper part of the bow. The beginning of the bow is likened to a trumpet; the edge is engrailed; the cross section of the bow is semicircular.
L: $2,3 \mathrm{~cm}$; W: $2,2 \mathrm{~cm}$; F.c.: stray find (GPS: $\mathrm{N}$ 632791 - E 148 485; surface).

Cat. 25. (Fig. 4.6)

A.N.: 30727.000 .168 .

Two-piece bronze brooch. The pin and the bow are semi-broken, the catchplate is missing. The pin is hinged in a narrow tube form from the top of the bow which is rolled back; the pin is fastened by an axis bar. The bow profile is slightly arched; the cross section of the bow is semicircular. There is a step at the junction of the bow and the hinged pin. The central knob is semicircular. The next part of the bow is rectangular, its edges are decorated with dots and its surface is decorated with enamelling: two small, black, rectangular enamel pieces.

L: $2,9 \mathrm{~cm}$; W: $2,6 \mathrm{~cm}$; F.c.: stray find (GPS: $\mathrm{N}$ 632732 - E $148402 ;-100 \mathrm{~cm}$ ).

Cat. 26. (Fig. 3.5)

A.N.: 30727.000 .157$.

Two-piece bronze brooch. The axis bar and the pin are missing. The flat plate forms a hare containing enamel cells with the outline of two small hares and a hexagram between them. The cells does not contain enamel anymore. The pin is hinged between two lugs behind the rump and the remain of the catchplate is behind the front legs. The face of the hare is complete with incised ears and a dotted eye.

L: $2,35 \mathrm{~cm}$; W: $1,65 \mathrm{~cm}$; F.c.: stray find (GPS: $\mathrm{N}$ 632723 - E 148465 ; surface).

Cat. 27. (Fig. 3.3)

A.N.: 30727.000 .155 .

One-piece bronze brooch. Almost complete. The spring is of 4+4 turns with an external chord; it is held by a prismatic hook and fastened by an axis bar. The flat plate forms an ungulate, decorated with chased dashes, the head is missing. The unperforated catchplate is rectangular.

L: $3 \mathrm{~cm}$; W: $2 \mathrm{~cm}$; F.c.: stray find (GPS: $\mathrm{N}$ 632749 - E 148 467; surface).

Cat. 28. (Fig. 3.4)

A.N.: 30727.409 .069 .

Two-piece bronze brooch. The bow is broken into two parts. The pin and the catchplate are broken. The pin is hinged between two lugs. 
The flat plate is in the shape of a goblet and two seahorses (?).

L: 2,2 cm; W: 3,1 cm; F.c.: OBJ: 409, STR: 564.

Cat. 29. (Fig. 5.5)

A.N.: 30727.000 .159 .

Fragmentary bronze brooch. The upper part of the bow only. The bow profile is highly arched; the cross section of the bow is rectangular. Originally there were two knobs on the top of the bow. One side is decorated with a knob and the other is decorated with a row of stamped horseshoe-shapes (12 pieces).

L: $3,8 \mathrm{~cm}$; W: $1,1 \mathrm{~cm}$; F.c.: stray find (GPS: $\mathrm{N}$ 632690 - E 148 461; surface).
Cat. 30.

A.N.: 30727.426 .016$.

Fragmentary bronze brooch. Pieces of the catchplate.

L: - W: - F.c.: OBJ: 426, STR: 581.

Cat. 31. (Fig. 5.4)

A.N.: 30727.000 .094$.

Fragmentary bronze brooch. Probably a piece of a catchplate; pierced by 18 holes; the edge is decorated with chased "Wolfszahnmuster".

L: $3,65 \mathrm{~cm} ; \mathrm{W}: 1,75 \mathrm{~cm}$; F.c.: stray find $(\mathrm{N}$ 632731 - E $148407 ;-120 \mathrm{~cm})$.

\section{References}

Almgren, O. 1923: Studien über nordeuropäischen Fibelformen der ersten nachchristlichen fahrhunderte mit Berücksichtigung der provinzialrömischen und südrussischen Formen. Leipzig.

BÁNKI, Zs. 1998: Kelten- und Eraviskergräber in Sárbogárd. Communicationes Archaeologicae Hungariae, 65-98.

BAyley, J. - Butcher, S. 2004: Roman Brooches in Britain. A Technological and Typological Study based on the Richborough Collection. London.

BeChert, T. 1973: Römische Fibeln des 1. und 2. Fahrhunderts n. Chr. Duisburg - Rheinhausen.

BERECZ, K. 1987: Adatok a térdfibulák pannoniai történetéhez. Unpublished MA-thesis. Budapest.

Berecz, K. 1990: Römerzeitliche Fibeln aus Zalalövő. Acta Archaeologica Academiae Scientiarum Hungaricae 42, 77-96.

BereCZ, K. 1991: Római kori fibulák Zala megyéből I. Zalai Múzeum 3, 163-183.

BereCz, K. 2008: Aucissa és emailos fibulák Pannoniában és a szomszédos barbaricumban. Unpublished $\mathrm{PhD}$-thesis. Budapest.

Berton, L. 2003: Les fibules zoomorphes gallo-romaines. Detection Passion mars/avr. 9, 1-9.

Bojović, D. 1983: Rimske fibule Singidunuma. Beograd.

BöHme, A. 1972: Die Fibeln der Kastelle Saalburg und Zugmantel. Saalburg Fahrbuch 29, 5-112.

Burger, A. 1972: Rómaikori temető Majson. Archaeologiai Értesítő 99, 64-100.

Cocış, S. 2004: Fibulele din Dacia romană - The Brooches from Roman Dacia. Institutul de Arheologie şi Istoria Artei Cluj-Napoca. Bibliotheca Ephemeris Napocensis 3. Cluj-Napoca.

Dollé, Ch. 1978: Les Fibules de Malain-Mediolanum. Cahiers de Memontois 32. Dijon.

Dollé, Ch. 1988: Les Fibules. In: Roussel, L. (ed.): Mediolanum: une bourgade gallo-romaine. Dijon, $74-85$

ETTLINGER, E. 1973: Die römischen Fibeln in der Schweiz. Bern.

Feugère, M. 1985: Les fibules en Gaule méridionale de la conquête à la fin du $V^{e}$ s. ap. J.-C. Revue archéologique de Narbonnaise Supplément 12. Paris. 
FüZEsI, A. 2012: Egy középső neolitikus település részlete Paks-Gyapa - Rosti-puszta lelőhelyről. Wosinsky Mór Múzeum Évkönyve 34, 7-41.

Garbsch, J. 1965: Die norisch-pannonische Frauentracht im 1. und 2. Fahrhundert. Münchner Beiträge zur Vor- und Frühgeschichte 11. München.

Hattatt, R. 1989: Ancient Brooches and other Artefacts. A Fourth Selection of Brooches together with some other Antiquities from the Author's Collection. Oxford.

JoBst, W. 1975: Die römischen Fibeln aus Lauriacum. Forschungen in Lauriacum 10. Linz.

KoczTur, É. 1991: Kora császárkori temető Solymáron. Studia Comitatensia 21, 171-334.

KoščEvić, R. 1980: Antičke fibule s područja Siska. Zagreb.

Kovrig, I. 1937: A császárkori fibulák fó formái Pannoniában. Dissertationes Pannonicae Ser. 2. No. 4. Budapest.

Kropf, W. - NowaK, H. 1998-1999: Fibeln von Flavia Solva aus Privatbesitz. Römisches Österreich $21 / 22,7-167$.

LamiovÁ-Schmiedlová, M. 1961: Spony z doby rímskej na Slovensku. Die Fibeln der Römerzeit in der Slowakei. Študijné Zvesti Archeologický Ústav Slovenskej Akadémie Vied 5. Nitra.

LERAT, L. 1956: Catalogue des collections archéologiques de Besançon II. Les fibules gallo-romaines. Annales Littéraires de l'Université de Besançon 16. Paris.

Márton, A. 2002: Roman Burial with a Weapon from the Bécsi road Cemetery (Aquincum - Budapest). Communicationes Archaeologicae Hungariae, 117-152.

Matouscheк, J. - Nowak, H. 1981-1982: Unpublizierte Hasen- und Hundefibeln aus Österreichischen Privatsammlungen. Mit einem Nachtrag: Pferde- und Reiterfibeln. Römisches Österreich 9-10, 131-182.

Matouscheк, J. - Nowak, H. 1985-1986: Unpublizierte Tierfibeln und Fibeln mit thermiomorphen Gestaltungselementen aus österreichischen Privatsammlungen. Römisches Österreich 13-14, $101-222$.

Merczi, M. 2011: Térdfibulák Komárom-Esztergom megyéből. Komárom-Esztergom Megyei Múzeumok Közleményei 17, 7-80.

Merczi, M. 2012: A Budaörs-Kamaraerdei-dülőben feltárt római vicus fibulái. In: OtTOMÁNYI, K. (ed.): Római vicus Budaörsön. Budapest, 473-528.

ORTISI, S. 2002: Die früh- und mittelkaiserzeitlichen Fibeln. Römische Kleinfunde aus Burghöfe 2. Frühgeschichtliche und provinzialrömische Archäologie, Materialien und Forschungen 6. Rahden.

Otтомányi, K. 2007: A pátyi római telep újabb kutatási eredményei. Studia Comitatensia 30, 7-238.

Palágyi, S. - Nagy, L. 2000: Római kori halomsírok a Dunántúlon. Veszprém.

Patek, E. 1942: A pannoniai fibulatípusok elterjedése és eredete. Dissertationes Pannonicae Ser. 2. No. 19. Budapest.

PEŠKǍ̌, I. 1972: Fibeln aus der römischen Kaiserzeit in Mähren. Praha.

Rieckнoff, S. 1975: Münzen und Fibeln aus dem Vicus des Kastells Hüfingen. Saalburg fahrbuch 32, 5-104.

RinA, E. 1979: Die Römischen Fibeln aus Augst und Kaiseraugst. Forschungen in Augst 3. Augst.

Riнa, E. 1994: Die Römischen Fibeln aus Augst und Kaiseraugst. Die Neufunde seit 1975. Forschungen in Augst 18. Augst. 
SÁRó, Cs. 2011: A pannoniai közép-dunai limes kora császárkori fibulatípusai. Unpublished MA-thesis. Budapest.

Schleiermacher, M. 1993: Die römischen Fibeln von Kempten-Cambodunum. Cambodunumforschungen $5,12-44$.

Sedlmayer, H. 2009: Die Fibeln von Magdalensberg. Funde der Grabungsjahre 1948-2002 und Altfunde des 19. Fahrhunderts. Klagenfurt am Wörthersee.

Sellye, I. 1939: Császárkori emailmunkák Pannoniából. Les bronzes emaillés de la Pannonie romaine. Dissertationes Pannonicae Ser. 2. No. 8. Budapest.

Simpson, G. 2000: Roman Weapons, Tools, Bronze Equipment and Brooches from Neuss-Novaesium Excavations 1955-1972. British Archaeological Reports - International Series 862. Oxford.

SNAPE, M. E. 1993: Roman Brooches from North Britain: A Classification and a Catalogue of Brooches from Sites on the Stanegate. British Archaeological Reports - British Series 235. Oxford.

VAdAY, A. 1988-1989: Die Sarmatischen Denkmäler des Komitats Szolnok. Antaeus 17-18, 9-351.

VÁGó, E. 1960: Kelten- und Eraviskengräber von Nagyvenyim und Sárkeszi. Alba Regia 1, 43-62. 


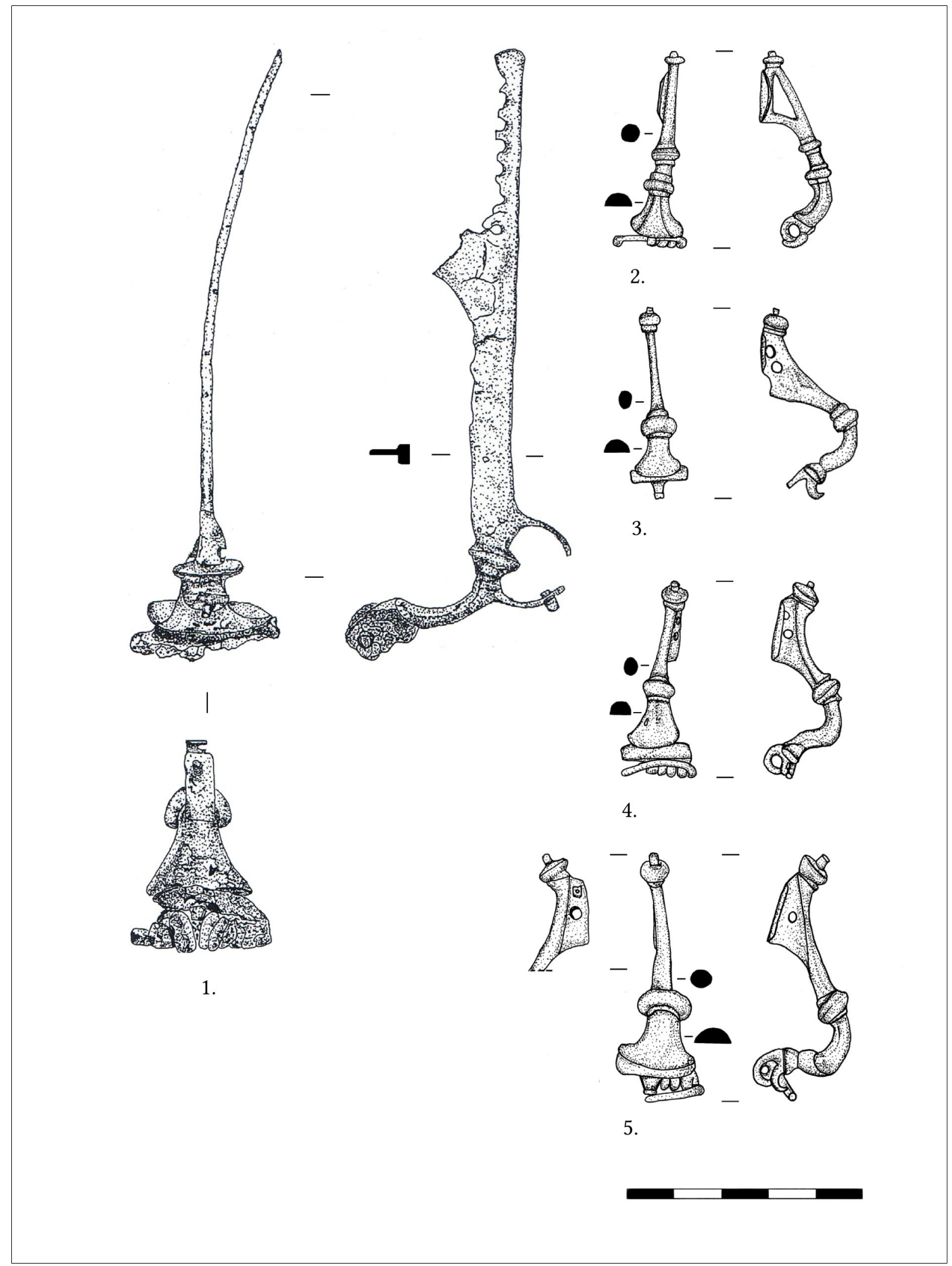

Fig. 1. 1. Cat. 2; 2. Cat. 6; 3. Cat. 8; 4. Cat. 10; 5. Cat. 11. 

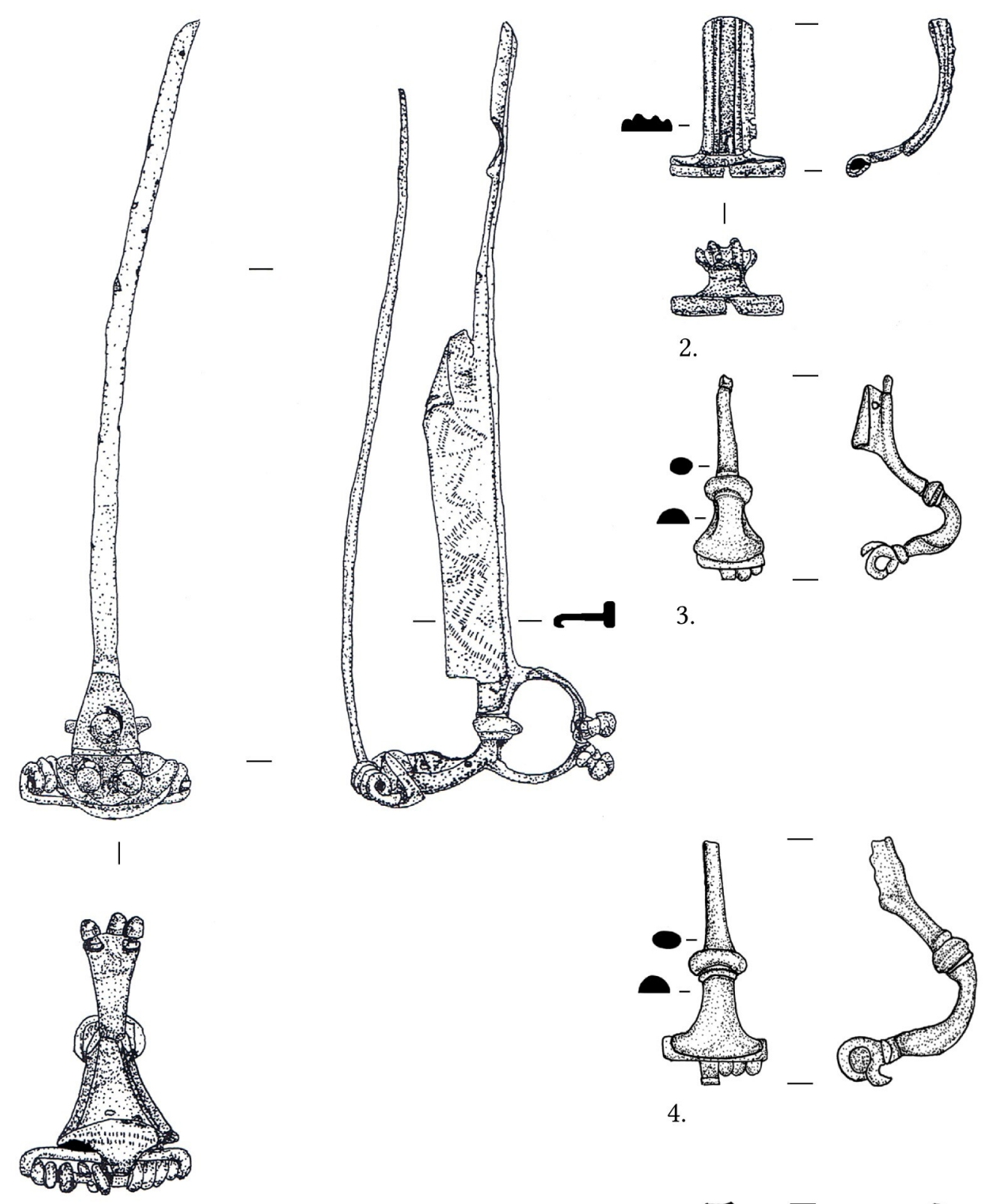

1.

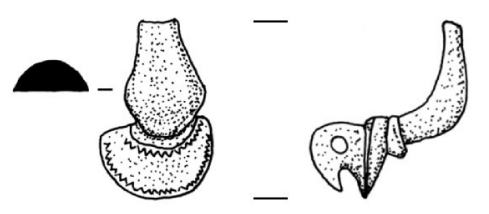

5.

Fig. 2. 1. Cat. 5; 2. Cat. 1; 3. Cat. 12; 4. Cat. 16; 5. Cat. 18. 


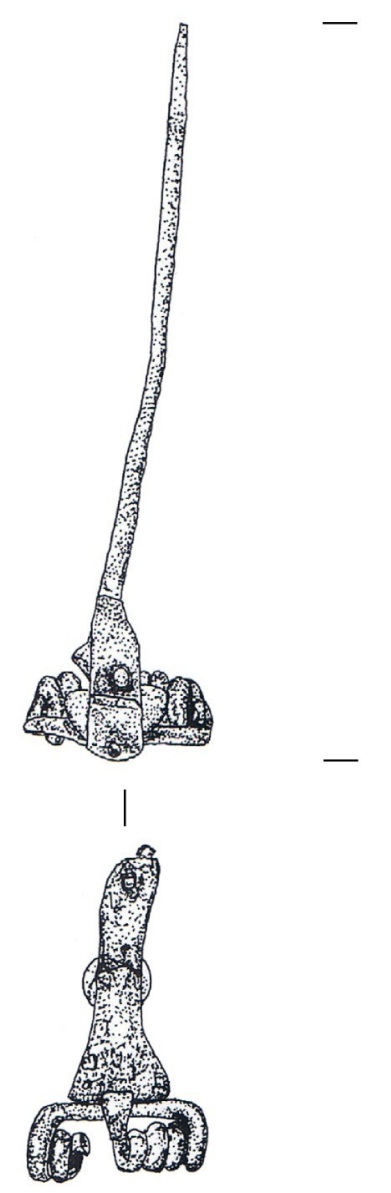

1.
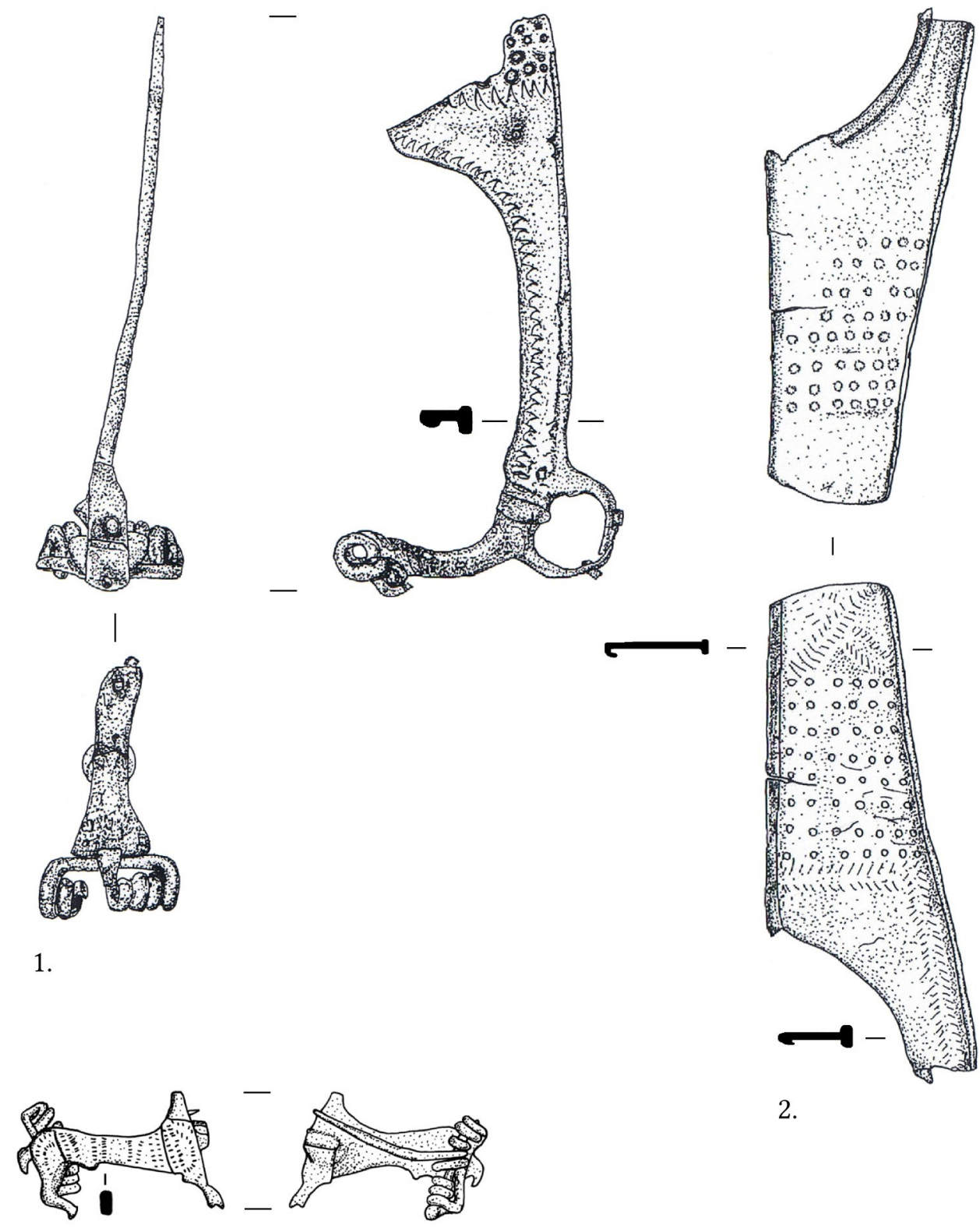

।

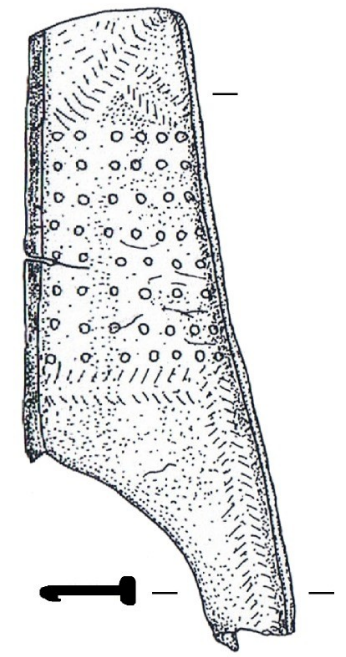

2.

3.

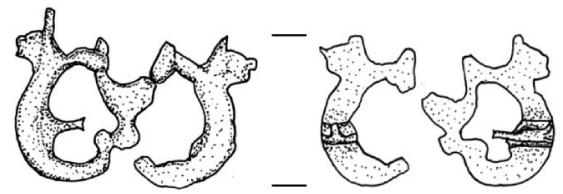

4.

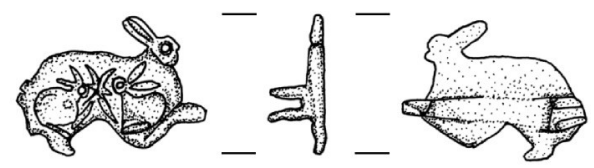

5.

Fig. 3. 1. Cat. 4; 2. Cat. 3; 3. Cat. 27; 4. Cat. 28; 5. Cat. 26. 


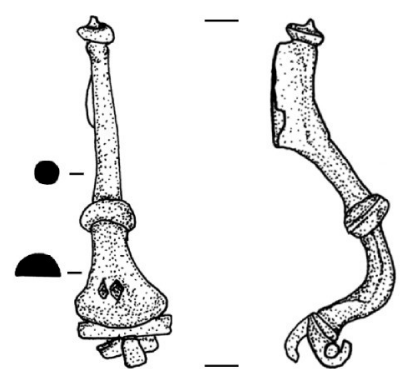

1.

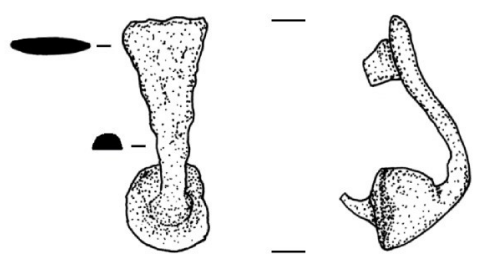

2

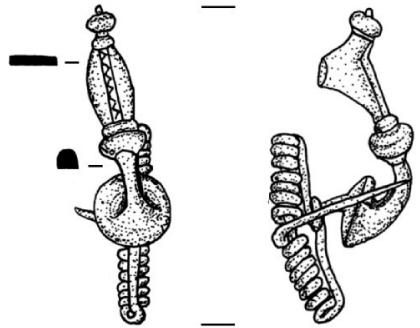

3.

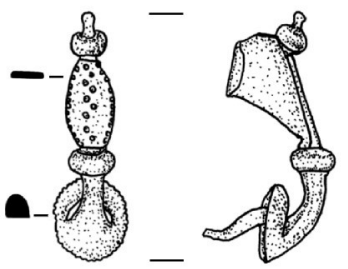

4.

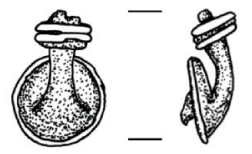

5 .
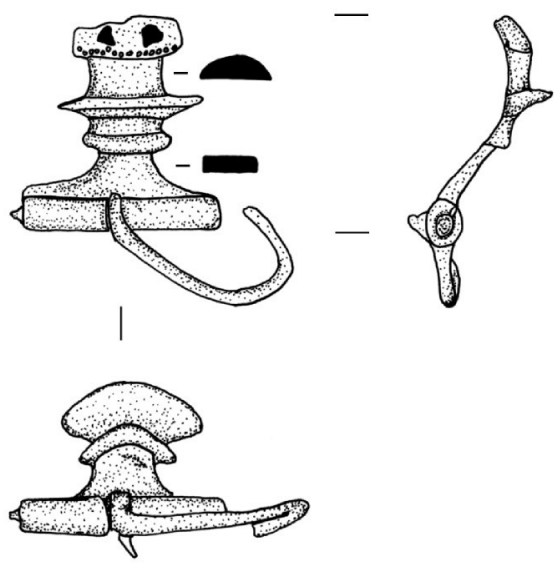

6.

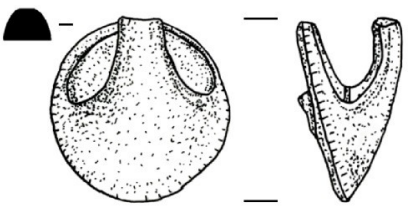

7.

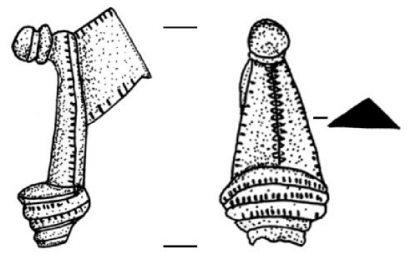

8.

Fig. 4. 1. Cat. 13; 2. Cat. 19; 3. Cat. 21; 4. Cat. 20; 5. Cat. 22; 6. Cat. 25; 7. Cat. 24; 8. Cat. 23. 


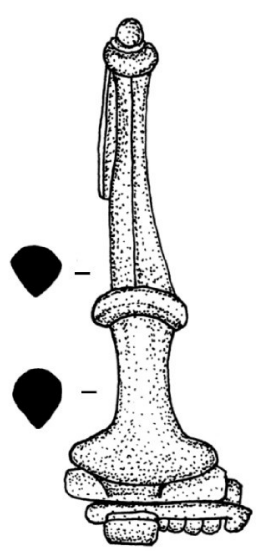

1.

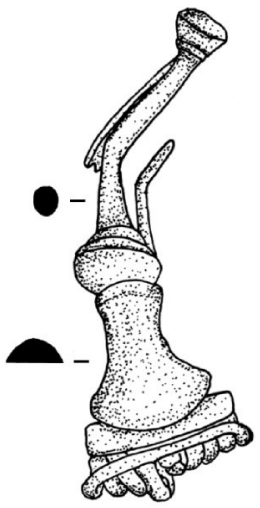

2.

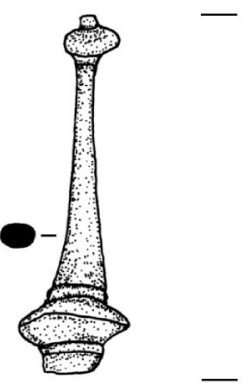

3.
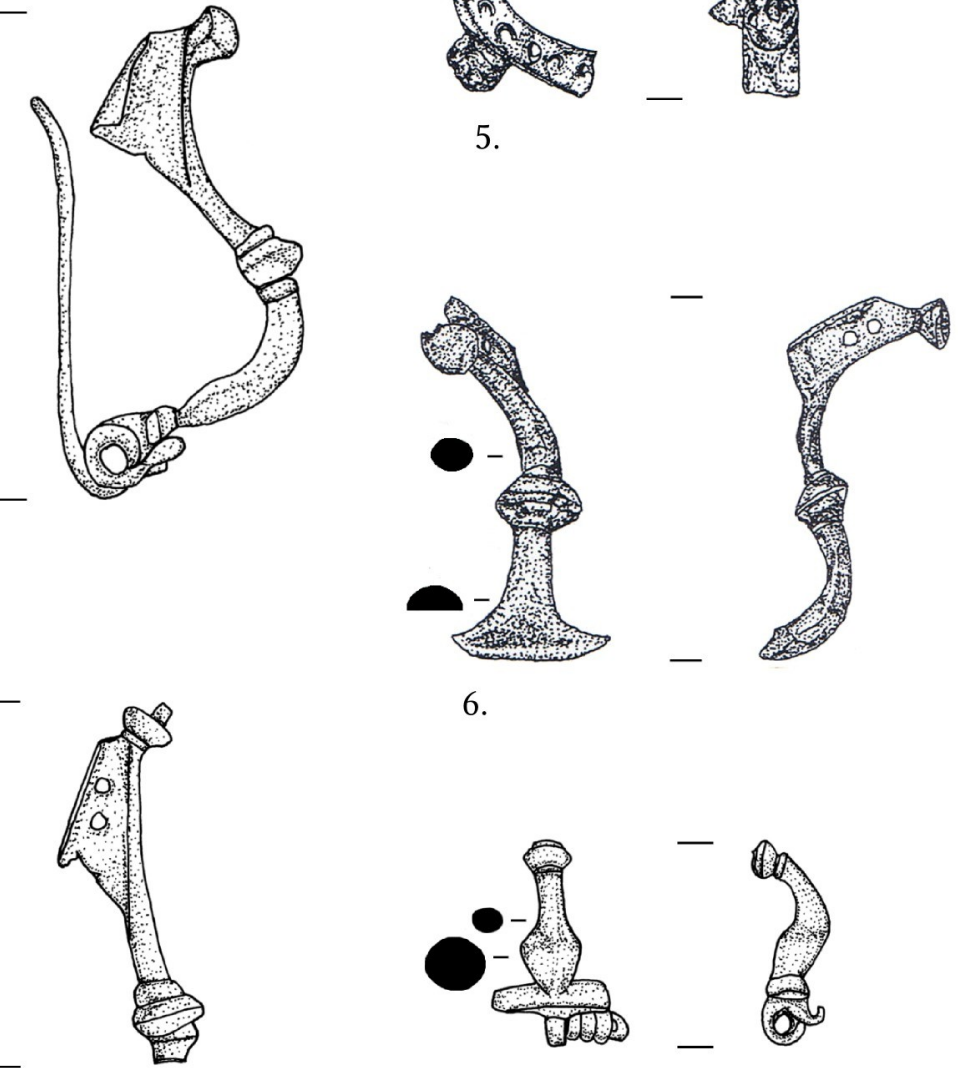

6.

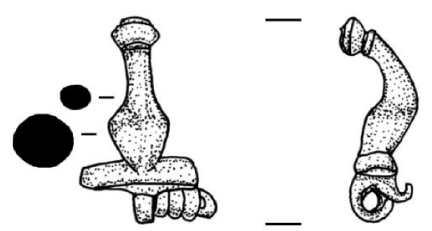

7.

Fig. 5. 1. Cat. 15; 2. Cat. 14; 3. Cat. 9; 4. Cat. 31; 5. Cat. 29; 6. Cat. 7; 7. Cat. 17. 